\title{
A Contrastive Study of Metathesis in English and Arabic
}

\section{Zainab Kadim Iggab \\ College of Education / \\ University of Thi-Qar}

\begin{abstract}
Metathesis is one of the prominent phenomena in some languages like English, Standard and colloquial Arabic and in the Semitic ones. It is available in the literatures of those languages. The aim of the study is to provide a solid theoretical background of metathesis in English and Arabic, and to understand it clearly in both languages in terms of contrastive points of view. The procedure of the study is that it is a descriptive contrastive study of metathesis in English and Arabic dealing with its etymology, sources, grammatical categories, rules, types, reasons, different points of view on metathesis, etc. A contrastive picture of metathesis in both languages is then given. The study data are taken from British and American dialects, and Standard Arabic and its dialects (Iraqi, Jordanian, Syrian, Makkan, Sudanese, Morrocan and Cairene). The findings of the study emphasize that the two languages are similar to each other in terms of metathesis definition and the problem of treating it, but they are different in terms of etymology, sources, rules, types, reasons and whether the form is original or metathetic. This study tries to abridge the gap in the current literature of contrastive studies in English and Arabic. The study consists of four sections, and ends with a list of references and two appendixes.
\end{abstract}

\section{Introduction:}

Metathesis is the phenomenon which indicates the reordering of two sounds in one word with a certain order in a reversal way in a related form of the same word.

Metathesis is a morphophonemic process by which elements of language, i.e. sounds, syllables in a word, words or other units in a sentence are interchanged or transposed. In general, it is called "?al-qalb ?al- Makäni", meaning that the places of sounds are changed. This process always occurs in spoken language. Wikipedia (2009) presents the following example: there is a difference between the spelling of the word 'iron' and its pronunciation that is usually produced by people, which is /'ai.ərn/ (see appendix I). Such a pronunciation gives us an idea that the word is 'eyern' not 'iron'. Another example given by Pyles and John (1982) is to make metathesis more clearly for the reader. 'Tax' and 'task' are two variants of one form which is produced with the sequence $/ \mathrm{ks} /$. In the metathetic form 'tax', /ks/ stands for ' $\mathrm{x}$ ' which is for task with /sk/. This phenomenon is clear in the words of many languages and also used as a regular part of some people's grammar. In the history of English, a change has happened on the shape of many known words by the process of metathesis (see also G and C. Merriam Co (1913); Gleason (1961: 86); Crystal, 2003: 291; RhymeZone (2009)).

The aim of this study is to describe metathesis in English and Arabic. Since this study is a contrastive descriptive, the procedures involve jaxtapositioning the etymology, sources, grammatical categories, rules, reasons and different points of view in English and Arabic, and making a contrastive study of metathesis in those two languages. This study is only concerned with metathesis, not any other morphophonemic process, in English and Arabic as represented by their dialects.

In the spoken chain, a change in the places of sounds can be found. Although inversion is opposed to metathesis, they can be considered as one case. When the sounds are close to 

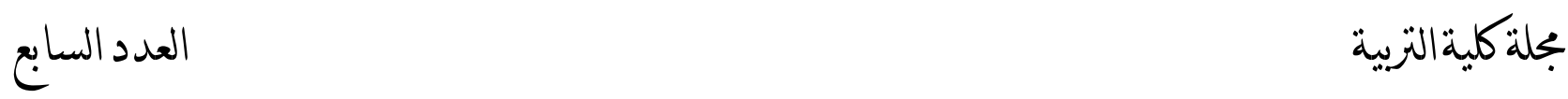

each other and the change of the places happens, this phenomenon is known as inversion, but when the sounds are not close to each other, i.e. there is a sound in between, it is called metathesis (Malmberg, 1963: 63). In some cases, those two phenomena are known as metathesis.

In English, the examples are taken from English and American dialects while the Arabic ones are taken from Standard Arabic and its different dialects: Iraqi, Jordanian, Sudanese, Syrian, Moroccan, Makkan and Cairene.

Since metathesis is a morphophonemic process consisting of two levels: morphology and phonology. Phonetics generally feeds phonology. So, three levels of language study are included: phonetics, phonology and morphology.

The data of the study are taken from Webster's Revised Unabridged Dictionary (1913); Malmberg (1963: 63); Al- Niaimi (1980); Pyles and John (1982); Lass (1984:188); Crystal (1992:249); Abdul- Al-Tawab (1997); Hanna et al (1997: 87); Al-Samerai (1998); Al-Siyoti (1998); Akmajian et al (2001: 493); Banjar (2003: 19-27); Minkova (2003); O'Grady et al (2005: 47-8); Al- Faysal (2007); Alpha Dictionary.com (2007); Casselman (2007: 10); Matthews (2007: 244); Parker (2009); The American Heritage Dictionary (2009); Wikipedia (2009); and the researcher's language repertoire (see appendix II).

\section{Metathesis in English and Arabic ${ }^{1}$}

\subsection{Etymology}

The word 'metathesis' is taken from Greek: 'meta' means "to change" and 'tithenai' means "to place or set" during Late Latin in the mid-16th century. So, metathesis means ' a change of position. Then, it moves to English language. This Greek term was invented by the firstcentury BCE Greek scholar, Dionysius of Halicarnassus. The method he used is basically re-writing documents in terms of a grammatical point of view which is changing the word and reordering the sentence. Such a method will result more fluent and natural texts. His editing methodology was known as metathesis Webster's New World College Dictionary (2005); Yehudim (2008); Nordquist (2009); Wikipedia (2009); ODLT; and Harper (2001)) who adds that metathesis belongs to 1660. WordNet (2001), the American Heritage® Dictionary of the English Language (2009) and Wikitionary (2009) give the same details but they add that metathesis is a late Latin expression taken from ancient Greek expression. The same is in Alpha Dictionary. Com (2007). But it adds that it means "between". It is also the same in Encarta Dictionary (2007) but it adds that it belongs to late 16th century. Parker (2009) gives its date circa 1538.

Concerning the origin of the type of metathesis in which /r/ and a vowel occur, the type of metathesis with its effects exist in the earliest Anglo- Saxon literature, throughout Medieval English, and in the New English period too. Shedding light on a number of distinct stages for $r$ - metathesis in Old English, like other processes, such as assimilation accompanied by the consonantal changes, is important. "The principle of rule ordering relevant to various phonological changes requires that metathesis in the earliest period of the history of English should be assigned to as many as four chronological stages, the first and the last in Anglian, the second (highly controversial) apparently in all dialects, and the third confined to West Saxon" (Stanley, 1952: 53; qtd in Welna 2008: 3). Regardless of

\footnotetext{
'The translation of every word in this research is done by the researcher with the aid of the following references: Al- Hamash (1986); Aziz (1989) and Baalbakani and Munir (2006).
} 
whether the information presented above about the chronological stages is right or wrong, the complicated scheme which belongs to Stanley explains that metathesis can not be considered as a change uniform chronologically and geographically.

On the other hand, in Arabic, metathesis was referred to by the ancient Arab linguists with examples, trying to explain that phenomenon by showing differentiation of languages, expansion in the language and the poetic necessity.

\subsection{Sources of Metathesis}

In English, there are three sources of metathesis. They are historical development, the child's speech and the speech of the adult. While in Arabic, there are two sources only not referring to historical development.

a. Historical development: Many words in English are formed by metathesis by being derived from Old or Middle English.

In Modern English, the word 'bird' is taken from Old English 'bridd' or 'bryd'; 'burn' from 'bren'; 'Manx' is taken from Middle English 'Manisk'; 'horse' is taken from 'hros'; 'wasp' is derived from 'wapse'; 'copse' from 'cosp' (copse) "fetter, bond"; 'crud' for 'curd'; 'aspe' from 'apse' "aspen"; 'wlips' from 'wlisp' "lisping"; 'hasp' from 'haps'; 'first' from 'frist'; 'beornan' (burn) from 'brinnan'; 'clapse' becomes 'clasp' in Modern English by a process of development from Middle to Modern English (Verma (1989: 71); McARTHUR (1998); Yule (2006: 188); Merriam Webster Online Dictionary (2009); the American Heritage Dictionary (2009); Webster's New World College Dictionary (2009); Wikipedia (2009). For Lass (1984: 188), the two words 'wapse' and 'copse' which result from metathesis, are now standard although the first one is found as 'wopse' in some dialects. In Yehudim (2009), it has been noted that from Old English 'thyrlian' and Middle English 'thirlen', the word 'thrill' in Modern English is derived. English native speakers change the place of $/ \mathrm{r}$ / to produce 'thrill' by the late 16 th century.

In Wikipedia (2009), the words 'ask' as /aks/ and 'ascian' 'axian' as 'acsian' are taken from Old English. The pronunciation of /aks/ can not be regarded as standard but it is a commonly regional one, as in: 'Don't aks me' (McARTHUR, 1998). That sequence has been found for so long (over 1.000 years). It should be considered as a part of English linguistic heritage as suggested by the liguist Mark Aronoff. Most people use 'axe' for 'aks' not 'ask'. In American English, the pronunciation /aks/ was the commonest in New England from original point of view. But then it began to disappear in the North early in the 19th century because it appeared in the South. Such a medial sequence /sk/ in Old English underwent metathesis to $/ \mathrm{ks} /$ in late West Saxon. For example, 'fiscas' $\rightarrow$ 'fixas' 'fishes'; 'wascan' $\rightarrow$ 'waxan' 'to wash'; 'dox' $\rightarrow$ 'dosc' 'desk'.

The sequence /ps/ in the metathetic form of the word 'wasp' which is 'waps' or 'wafs', became difficult to produce at a certain period of time, so the Anglo- Saxons made a switch between the two consonants in the consonant cluster/ps/ which is /sp/ (Casselman, 2007: 9). In ODLT, the same is with the word 'third' is taken from 'thridda' (Anglo-Saxon).

The words in Modern English, which are derived from Middle English, are described as being more stable than those taken from Old English because they keep their own metathetic forms (Welna, 2008: 1).

On the other hand, there are no examples of metathesis in Arabic which prove that historical development is not a source of metathesis.

\section{b. In the child's speech}


Metathesis is used as a change of sound which commonly occurs in a child language (Malmberg, 1963: 63; Welna, 2008: 2). Many kinds of metathetic forms are considered as speech errors, according to many linguists. Children are not like adults in the ability to pronounce all the consonant sequences, as in: 'spaghetti' is produced by English- speaking child when a child has learned to read as 'pesghetti' /pəsketi/. Because children can not pronounce the first syllable 'spa', they pronounce it as /pəs/. This interchange proves that most English speakers acquire a 'pVs' before they become able to pronounce the consonant cluster /sp/ (O'Grady et al, 2005: 47-8; Casselman, 2007: 10; and Wikipedia, 2009).

In some words, it is a matter of preference by children for certain sequences rather than others. For example, the children tend to pronounce the words 'breakfast' and 'hospital' as /breifkast/, /hopsitl/. /kf/ and /sp/ are clusters which are not preferred across languages compared to /fk/ and /ps/ (Tessier, 2007: 1).

On the other hand, in Arabic, the children who are of three or four years age, tend to use metathetic forms in their speech. Such forms are to be diminished as they grow up and begin imitating the adults' speech (Abdul-Tawab, 1997: 92) or continue using such forms if they see that they are available in the language of the adults:

$$
\begin{aligned}
& \text { Jazma } \rightarrow \text { jamza "shoes" } \\
& \text { fara } \int \text { a } \rightarrow \text { fa } \int \text { ara "butterfly" } \\
& \text { mismar } \rightarrow \text { mimsar "nail" }
\end{aligned}
$$

\section{c. In the adults' speech}

Metathetic sequences of sounds which are 'wrong', also develop in the adult's language. On the phonological level, it indicates a change in the place of two sounds which looks as if it was a performance error, i.e. in tongue- slips by adults, as in: 'aks' for 'ask' is still used in some American dialects, as in: 'I aksed him already'.

The expression 'pretty good' is produced by adults like the 'cowboy' as 'purty good', which is considered as a dialect variant within Modern English. It is found in everyday speech (Yule, 2006: 188). One type of metathesis which is commonly used is in the phonetic situation of $/ \mathrm{r} /$ plus a vowel. So, the previous word 'pretty' is said as 'perti' when it is pronounced with a minimal stress. Such words in which $/ \mathrm{r} / \mathrm{plus}$ a vowel are used, are pronounced with unstressed position. In addition, many metathesized "er"s are found in the speech of educated people (Wikipedia, 2009).

The rules of adult metathetic forms are different from those which govern those forms in child's speech (Crystal, 1992:249; Welna, 2008: 2).

O'Grady et al (2005: 48); Encarta (2009); Merriam Webster Online Dictionary (2009), among others give examples to prove that the metathetic forms result from "mispronunciation" or "a tongue- slip" like I'pər-tē for 'pretty', 'prescribe' and 'prescription' as 'perscribe' and 'perscription' in which the two consonants /r/ which follow each other, are easy to pronounce in terms of metathesis. No one can say that since metathetic forms are parts of language, they are used as being original by the speakers who become unable to differentiate metathetic from original forms.

Metathesis is occasionally found in the speech of learners and native speakers as well. But when it is of common and regular use by native speakers, there will be a change in the word itself. So, in Modern English, the word 'bird' is taken from 'brid' "young bird" (Richards, 1992: 228). 
On the other hand, in Arabic, metathesis is used in our everyday adult speech. This is because of the linguistic regional differences. In some words, the two sounds can be adjacent in one dialect but non- adjacent in another one. For example, $/ \mathrm{r} / \mathrm{and} / \mathrm{j} /$ are nonadjacent in a word taken from Standard Arabic: 'Habajir' $\rightarrow$ 'Habarij' "the males of the bustard" but they are used as adjacent in the metathetic form of the word: 'rijlïn' $\rightarrow$ 'ijrïn' "the feet" (Jordanian Arabic).

\subsection{Grammatical Categories}

In English, the two sounds which replace each other in terms of their places in a word can exist in different grammatical categories of words, i.e. nouns, such as 'brid' for 'bird'; adjectives, such as 'beorht brigt' which is taken from Old English for 'bright'; and verbs, such as 'irnan rinnan' which is derived from Old English for 'run' (Welna, 2008: 1). When the original English form changes to a metathetic one, it keeps its own meaning and part of speech.

In Arabic, the original and metathetic forms can either be nouns like 'Säçiqah' $\rightarrow$ 'Sägçah' "thunder"; adjectives like 'mukfahar' $\rightarrow$ 'mukrahaf' "to become dark"; or verbs like 'jaðab' $\rightarrow$ 'jabað' " to attract". In addition, the two forms are similar to each other in meaning and part of speech and they are not affected by the change from the original to the metathetic.

\subsection{Rules for Metathesis Formation}

Metathesis is regarded as one of the various kinds of operations (processes) which can be performed by phonological rules. For example, [aks] for 'ask' (Hyman, 1975: 14-5). This phenomenon is accompanied by a change in the places of sounds which are either adjacent or non- adjacent. The examples for adjacent sounds are taken from Old English: 'waps' $\rightarrow$ 'wasp', 'pridda' $\rightarrow$ 'pirdda' "third", and the ones for non- adjacent sounds exist in other languages (O'Grady et al, 2005: 253):

1. The adjacent / $/$ and /i/ change their places in 'foilage' is used with its metathetic form which is foliage, 'flimsy' $\rightarrow$ 'filmsy'; 'film' $\rightarrow$ 'flim' (Alpha Dictionary. Com (2007); Wikipedia (2009)).

2. A sound moves from one syllable into another ('pistris' for 'pristis') (Webster's 1828 Dictionary; Compact Oxford English Dictionary (2009). In Parker (2009), sometimes, in the compound words, a sound like $/ \mathrm{r} /$ moves from the first syllable to the second one, for example, 'daggle- trail' for 'draggle- tail'.

3. /r/ and a vowel are the most common sounds which are switched in the metathetic form. For example, 'pretty' in: 'She's a pretty girl' is pronounced as /priti/. But in 'That's pretty good' in which 'pretty' is produced with minimal stress, it will be /pərti/. Other examples are 'hundred, apron, pronounce'. When every word has /r/ plus a vowel which is said in an unstressed syllable, the two sounds are re-ordered to be /or/s in the speech of educated people. So, the re-ordering is connected with an unstressed position where the word is used. Other examples are 'meagre' for 'meager'; 'perogative' for 'prerogative'; 'perscription' for 'prescription'; 'differnce' for 'difference'; 'prescribe' for 'prescribe'; 'modren' for 'modern' (Webster's Revised Unabridged Dictionary (1913);(O'Grady et al, 2005: 47-8); Alpha Dictionary.Com (2007); American Heritage Dictionary (2009).

4. The adjacent / $\mathrm{k} /$ and /s/ are changed in their places ('aks' for 'ask'); /'astəriks/ for 'asterisk'; 'desk' for /dəks/. But the medial sequence /sk/ in Old English underwent metathesis to /ks/ 
in late West Saxon. From a diachronic point of view, the root final cluster which includes /k/ followed by /s/ is transposed (AllWords.com Multi- Lingual Dictionary (2009) and Wikitionary (2009).

5. The sequence /sp/ which is found in the onset of an unstressed syllable is metathesized as /ps/, for example, 'psketti' for 'spaghetti' (Minkova, 2003). In 'waps' or 'wafs' which is taken from Old English and then it becomes 'wasp', the places of the $/ \mathrm{s} /$ and $/ \mathrm{p} /$ are changed. Those two consonants occur successively in the word. So, instead of $/ \mathrm{p} /+/ \mathrm{s} /$, it will be $/ \mathrm{s} /+$ /p/ (Matthews, 2007: 244). As a common and universal fact, an alveolar consonant /s/ moves to the end of the word, i.e., to follow another consonant like bilabial /p/ and velar $/ \mathrm{k} /$. 6 . /n/ and /i/ replace each other, in, for example, 'larnyx' for 'larynx'.

7. In a number of words like 'another', their sounds and syllables which are metathesized, result in reinterpretation of its original form, i.e. 'an other' to be 'a nother'. It is particularly used in the expression 'a whole nother thing' (Pyles and John, 1982).

8. The /l/ and /v/ can be adjacent in /'kalvəri/ for 'cavalry'/'kavlri/ or non- adjacent in /'revələnt/ for 'relevant' /'reləvənt/ because of /ə/ insertion (Wikipedia, 2009).

9. In words like 'comfortable', /r/ is silent /'k^mftəbl/, but in its metathetic form, it will be pronounced and the insertion of schwa between the two consonants in a consonant cluster is done. So, the metathetic form is /'k^mftərbəl/. /t/ and /r/ are switched, the number of the syllables which is four is decreased into three syllables (Dictinary.com Unabridged (2009).

10. In words like 'introduce' /introdju:s/, /r/ is followed by a schwa, but when it is metathesized, its pronunciation will be /intərdju:s/ in which schwa precedes /r/ instead of following it. It is the same in 'pernunciation' for 'pronunciation' in which $/ \mathrm{r} /$ changes its place accompanied by a change in the vowel, i.e. instead of /o/, /e/ is used (Casselman, 2007: 10).

11. When a word, such as 'integral'/intigrəl/, is to be metathetic, its pronunciation will be /intrəgəl/ in which the two sounds /g/ and /r/ switch their places with insertion of a schwa sound between the two sounds in addition to the deletion of /i/.

12. In 'nuclear' which is pronounced as /nju:kliə/, its metathetic form is /nukular/.

13. /r, 1/ are metathesized in, for example, 'miraculum' $\rightarrow$ 'milagro' (Malmberg, 1963: 63).

$14 . / \mathrm{m} /$ and $/ \mathrm{n} /$ can either be adjacent in 'emnity' $\rightarrow$ 'enmity' or non- adjacent in 'animal' $\rightarrow$ /aminəl/; 'anemone' $\rightarrow$ 'anenome'; which is close to be standard because it is used by many people, even the gardening experts.

Those changes of places are lexeme-specific which are commonly found with metathesis. This is because no one has found the following in English: 'phomene, phenonemon, anemity, amaenia' (Lass, 1984: 188).

15. The non adjacent $/ \mathrm{d} 3 /$ and $/ \mathrm{d} /$ are switched in 'tradegy' /trædəd3i/ for 'tragedy'/træd3ədi/.

16. The non adjacent $/ \mathrm{m} /$ and $/ \mathrm{g} /$ are interchanged in 'almug' for 'algum'. In this instance, /məg/ becomes /gəm/.

17. The /e/ is omitted in 'intersting' /intərsting/ for 'interesting' /intəresting/ (Parker, 2009).

18. The adjacent /l/ and /ə/ are interchanged in: 'julary' /joolərie/ for 'jewelry' /joowəlrie/ (ibid).

19. Metathesis could be a change in the places of syllables, as in: "You occupew my pie [py] for " You occupy my pew" (ibid).

20. Metathesis also exists in the phenomenon of spoonerisms, as in: 'the dear old queen'

$\rightarrow$ 'the queer old dean' (Crystal, 1992: 249). 
21. The distinctive features of two sounds can be switched in a word, as in: difficult $\rightarrow$ /gipətul/ in which the first consonant /d/ becomes /g/ and the third one / $/$ / becomes /t/. There is no change in the places of the other segments in the word. There is no change in the voicing feature: $/ \mathrm{d} /$ and $/ \mathrm{g} /$ are voiced and $/ \mathrm{k} /$ and $/ \mathrm{t} /$ are voiceless, but the two features (backness) and (coronality) are changed: [ + back, - coronal $] \rightarrow[-$ back, + coronal $]$ and [back, + coronal $] \rightarrow[+$ back, - coronal $]$. So, the change is not in the redundant feature but in the distinctive features of the sounds. It is not necessary to find all the features changed, but some of them are changed and others are not (Akmajian et al, 2001: 493).

In Standard Arabic, it is known that if 'waw' or 'ya?' move in a word and fatHah ${ }^{2}$ is placed on the sound which precedes them, 'waw' or 'ya?' is changed to alif, for example, 'saçiya' "to attempt" and its original form is 'saça', 'daça' "He called, summoned, invited" and its original form is 'daçu'. But if 'waw' or 'ya?' are preceded by a sound on which kasrah or Damah is placed, 'waw' or 'ya?' is not changed into 'alif', such as: 'raDiya' "He satisfied" in which 'ya?' is not changed into 'alif' and the same is with 'sarü' "They walked" in which 'waw' is not changed (Abdul- Tawab, 1988: 237 and Hassan, 2004: 276).

On the other hand, in Arabic, a full- description of the interchanging sounds is given in terms of rules:

1. $/ \mathrm{m} /$ and $/ 1 /$ are switched in, for example, 'zambalak' $\rightarrow$ 'zalambak' "spring" (Makkan dialect). They move from one syllable into another. 'qaSmalat' $\rightarrow$ 'qaSlamat' "to break something" (Standard Aarbic).

2. The metathetic forms of 'yantafiD' are 'yiTnafiD' in Makkan and 'yiTnifiD' in Cairene "he shakes", and of '?intafaf' are '?atnafaf' in Makkan and '?itnafaf' in Cairene " puffed up". The adjacent /n/ and /t/ are interchanged. From /nt/ to /Tn/ or /tn/. An example from Standard Arabic is 'qaniit' $\rightarrow$ 'qatïn' " to be obedient".

3. The non- adjacent $/ \mathrm{n} /$ and $/ 1 /$ change their places in one word with other changes like doubling a consonant or $/ \mathrm{j} /$ is changed to $/ \mathrm{g} /$ or $/ \ddot{a} /$ and/i// are changed to /e/. For example, 'banalti' $\rightarrow$ 'balanti' "penalty"; 'fanillah' $\rightarrow$ 'falïnna' "T-shirt"; 'fannäyil' $\rightarrow$ 'falläyin' "Tshirts"; 'fanilyä' $\rightarrow$ 'falinya' "vanilla"; 'junillah' $\rightarrow$ 'glinnah' "skirt"; 'junillät' $\rightarrow$ 'glinnät' "skirts" in Makkan Arabic. But in Cairene Arabic, the metathetic forms of the previous words are $\rightarrow$ 'balanti'; 'falenna'; 'falennät'; 'falenya'. Other examples taken from Makkan and Cairene are 'yalçan' $\rightarrow$ 'yinçal' " he curses"; 'laçnah' $\rightarrow$ 'naçlah' "curse"; 'laçan' $\rightarrow$ 'naçal' "cursed".

4. The adjacent /l/ and /ç/ are changed in their places in a word. The example taken from Makkan is 'milçaqah' $\rightarrow$ 'miçlaga' "spoon" and in Cairene 'maçla?a' and 'maläçiq' $\rightarrow$ 'maçäli?' "spoons" but in Standard Arabic, 'milçaqa' $\rightarrow$ 'miçlaqa'.

5. The non- adjacent $/ / /$ and $/ r /$ are switched in a word. In Cairene Arabic, 'litr' $\rightarrow$ 'ritl' "litre" and 'silindar' $\rightarrow$ 'srindel' but in Makkan, it becomes 'srindal' "cylinder". In Standard Arabic, 'laçamri' $\rightarrow$ 'raçamli'.

6. The adjacent /1/ /H/ exist in the word 'sulHufäh' $\rightarrow$ 'suHlufah' in makkan and 'ziHlifah' in Cairene "turtle".

7. The two adjacent $/ 1 /$ and /t/ are interchanged in the following examples. In Makkan, '?iltaqa' $\rightarrow$ '?atlaga' "to be found"; '?iltabas' $\rightarrow$ '?atlabas' "to be mixed up". The examples taken from Makkan and Cairene are: '?iltaHaf' $\rightarrow$ '?atlaHHaf" "to wrap oneself"; '?iltawwa' $\rightarrow$ '?atlawwa' "to twist oneself"; '?iltaHam' $\rightarrow$ '?atlaHam' "to solder";

\footnotetext{
FatHa, kasra and Damah represent the pure Arabic vowels and they correspond to the English /a, I, u/.
} 
العدد السابح

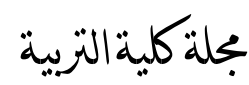

'?iltasaç' $\rightarrow$ '?atlasaç' "to be burnt". But in Cairene Arabic, they become: '?itlaHHif', '?itlawwa', '?itlaHam', '?itlasaç'. In Iraqi dialect: 'labtob' $\rightarrow$ 'tablob' "portable computer"; 'katalok' $\rightarrow$ 'kalatok' "catalogue".

8. The non- adjacent $/ \mathrm{l} /$ and $/ \mathrm{x} /$ are metathesized in the example: 'xallaT' $\rightarrow$ 'laxbaT' "mixed things" (Makkan and Cairene Arabic).

9. The non- adjacent / $/$ / and $/ \mathrm{j} /$ are switched in the examples which are taken from Makkan Arabic: 'zanjabïl' $\rightarrow$ 'janzabïl' "ginger"; 'zinjibär' $\rightarrow$ 'jinzibär' "Zanzibar"; 'zawj' $\rightarrow$ 'jöz' "husband"; '?azwäj' $\rightarrow$ 'jizän' "husbands"; '?azwäj' $\rightarrow$ '?ajwäz' "couples"; 'zawäj' $\rightarrow$ 'juwäz' "marriage"; 'lazij' $\rightarrow$ 'lijiz' "sticky". A number of those examples are taken from Cairene Arabic in which /j/ is changed into the velar /g/: $\rightarrow$ 'ganzabïl'; $\rightarrow$ 'göz'; $\rightarrow$ '?agwäz'; $\rightarrow$ ' gawäz'. In Standard Arabic, 'zujaj' $\rightarrow$ 'jizaz' "glass"; 'zajal' $\rightarrow$ 'jazal' "to let go the pigeon".

10. The adjacent $/ \mathrm{s} /$ and $/ \mathrm{r} /$ are switched in a word which is taken from Makkan Arabic: 'masraH' $\rightarrow$ 'marsaH' "theatre".

11. The adjacent $/ \mathrm{r} /$ and $/ \mathrm{T} /$ are interchanged in the following examples: 'barTamän' $\rightarrow$ 'baTramän' "jar"; 'barTamänät' $\rightarrow$ 'baTramänät' "jars" (Makkan and Cairene Arabic).

12. The non- adjacent $/ \mathrm{r} /$ and $/ \mathrm{n} /$ are switched in the example: '?aränib' $\rightarrow$ '?anärib'

"rabbits" (Cairene Arabic). In Standard Arabic, 'narjis' $\rightarrow$ 'ranjis' " narcissus".

13. The non- adjacent /H/ and /f/ exist in the examples: 'Hafar' $\rightarrow$ 'faHat' "dug"; 'yaHfir' $\rightarrow$ 'yifHat' "he digs"; 'Haffärah' $\rightarrow$ 'faHHära' "mechanical shovel" (Cairene). There is a change in the consonant /r/ to /t/. In Stnadard Arabic, 'lafaHat' $\rightarrow$ 'laHafat' "to burn".

14. The non adjacent /s/ and /f/ are transposed in 'falsafah' $\rightarrow$ 'falfasa' "philosophy"; 'xasaf' $\rightarrow$ 'xafas' "lowered"; 'yaxsif' $\rightarrow$ 'yixfis' "he lowers" (Makkan and Cairene). The examples from Standard Arabic are 'krasif' , 'krafis' "cotton" and 'safiT' , 'fasiT' "invaluable thing".

15. A change happens on the non- adjacent /f/ and /q/. They change their places with each other but /q/ will be replaced by /?/, as in the instances: 'Saffaq' $\rightarrow$ 'sa??af' "clapped"; 'yuSaffiq' $\rightarrow$ 'yisa??f' "he claps"; 'taSfiq' $\rightarrow$ 'tas?if' "clapping" (Cairene Arabic).

16. The adjacent /r/ and /f/ are interchanged in the examples: 'narfaz' $\rightarrow$ 'nafraz' "got nervous"; 'narfazah' $\rightarrow$ 'nafrazah' "getting nervous" (Makkan and Cairene) and 'frSa', 'rfSa' "the time when they go to water" (Standard Arabic).

17. The two adjacent /f/ and /w/ are switched in the example: 'tafwiD' $\rightarrow$ 'tawfiD' "authorization" (Makkan and Cairene).

18. The adjacent $/ \mathrm{z} /$ and $/ \mathrm{r} / \mathrm{change}$ their places in the following word taken from Makkan Arabic: 'mizräb' $\rightarrow$ 'mirzäb' "spout".

19. The /r/ and /y/ which are adjacent in the original word and non- adjacent in the metathetic form are switched in the example taken from Makkan Arabic: 'Hawäry' $\rightarrow$ 'Hawäyir' "districts". They become non- adjacent because the short vowel /i/ is inserted.

20. The non- adjacent /k/ and /?/ are interchanged in 'ka?ib' $\rightarrow$ '?ikib' "sad" (Cairene Arabic).

21. The adjacent $/ \mathrm{k} /$ and $/ \mathrm{t} /$ change their places in the instance taken from Makkan Arabic: '?iktawa' $\rightarrow$ '?atkawa' "to suffer".

22. The metathetic form for 'fahranhäyit' is 'farhanhäyit' "Fahrenheit" in Makkan and Cairene Arabic, and for 'kahrabä?' is 'karhaba' "electricity" in Makkan Arabic. In those examples, the adjacent fricative $/ \mathrm{h} /$ and $/ \mathrm{r} /$ are switched. 
23. The non-adjacent $/ \mathrm{t} /$ and $/ \mathrm{b} /$ are transposed in a word which is taken from Cairene Arabic: 'täbiç' $\rightarrow$ 'bitäç' "to belong". In Standard Arabic, 'tabal' , 'batal' "cutting".

24. The non-adjacent /ð/ and /b/ are switched in a word which is used in Standard Arabic: 'jaðab' $\rightarrow$ 'jabað', "pulled towards", but in Makkan Arabic, in the metathetic form, /ð/ is changed to /d/ which is 'jabad'.

25. The non-adjacent $/ \mathrm{w} /$ and $/ \mathrm{m} /$ change their places in the metathetic form found in Makkan, Cairene and Standard Arabic: 'çawämïd' $\rightarrow$ 'çamäwïd' "pillars"; 'qawämïs' $\rightarrow$ 'qamäwïs' "dictionaries".

26. The $/ \mathrm{b} /$ and $/ \mathrm{h} /$ are non-adjacent in the Standard Arabic but they are adjacent in the metathesized forms found in Makkan and Cairene Arabic: '?ablah' $\rightarrow$ '?ahbal' "stupid".

27. The non-adjacent $/ \mathrm{H} /$ and $/ \mathrm{m} /$ are interchanged in a word but $/ \mathrm{m} /$ will be changed to $/ \mathrm{b} /$ in the metathetic form and there is another change which is the /q/ that changes to $/ \mathrm{g} / \mathrm{in}$ Makkan and /?/ in Cairene. So, 'Hamlaq' $\rightarrow$ 'baHlag' and 'baHla?' "stared". In Standard Arabic, 'Hamat' $\rightarrow$ 'maHat' "strong hotness"; 'TarmoH' $\rightarrow$ 'TarHom' "long". While the two sounds become adjacent in 'daHmalat' $\rightarrow$ 'damHala' "to roll along the ground".

28. The adjacent /H/ and /t/ are switched in a word like '?iHtaraq' " to burn oneself" to produce '?atHarag' in Makkan Arabic and '?itHara?' in Cairene Arabic.

29. The non-adjacent $/ \mathrm{s} /$ and $/ \mathrm{m} /$ change their places in a word like 'dassam' "to enrich something with fat" to be 'dammas' in Makkan and 'dassim' in Cairene.

30. The adjacent $/ \mathrm{r} /$ and /t/ are switched in a word. For example, '?irtaxa' "to relax oneself" $\rightarrow$ '?atraxa' in Makkan and '?itraxa' in Cairene; '?irtama' "to throw oneself" $\rightarrow$ '?atrama' '?itrama'.

31. The adjacent $/ \mathrm{t} /$ and $/ \mathrm{J} /$ are interchanged to produce 'kot $\int \mathbf{i n a}^{\prime} \rightarrow$ 'k $\int$ tina' "a game of cards".

32. In 'Säçiqah' "thunder" from Standard Arabic, the non-adjacent /ç/ and /q/ will be adjacent and /q/ is to change to /g/ in the metathetic form taken from Makkan Arabic: 'Sägçah'. 'qubaça' $\rightarrow$ 'baqaça' "the servant who shows and hides her face" (Standard Arabic).

33. The non-adjacent $/ \mathrm{m} /$ and $/ \mathrm{r} /$ in 'tamartay' " to roll around" will be adjacent in the metathetic form '?addarmay' in Makkan Arabic. In Standard Arabic, they are non-adjacent, as in: 'yaðrama' , 'yaðmara' " confusion of speech".

34. The adjacent /T/ and /y/ are found in 'aTyab' $\rightarrow$ 'ayTab' "better" (Standard Arabic).

35. The adjacent /D/ and /m/ are found in 'iDmaHal' $\rightarrow$ 'imDaHal' "to disappear" (Standard Arabic).

36. In Standard Arabic, the non-adjacent /ç/ and /m/ exist in 'çamïq' $\rightarrow$ 'maçïq' "deep"; 'çamaj' $\rightarrow$ 'maçaj' "a person who is walking fast".

37. In Standard Arabic, the non-adjacent /l/ and /b/ are used in 'mukabal' $\rightarrow$ 'mukalab' "chained".

38. The adjacent /s/ and /b/ are found in 'basbas', 'sabsab' "desert".

39. The non-adjacent /f/ and /h/, 'mukfahar' $\rightarrow$ 'mukrahaf' "gloomy clouds"; 'hafa' $\rightarrow$ 'faha' "to pass swiftly".

40. The non-adjacent /r/ and /z/ exist in 'Dimriz' $\rightarrow$ 'Dimzir' "old camel"; 'Damäriz' $\rightarrow$ 'Damäzir' "old camels".

41. The non-adjacent $/ \mathrm{m} /$ and / $/$ / are used in 'Tämis' $\rightarrow$ 'Täsim' "extinct, dead".

42. The non-adjacent /ç/ and /T/ are found in 'qarçaTuba' $\rightarrow$ 'qarTaçuba' "a person who has no more or less". 
43. The non-adjacent /r/ and / $\mathrm{x} /$ exist in ' $\int \mathbf{a r i x}$ ' $\rightarrow$ ' 'axira' "to become a youth".

44. The adjacent /n/ and /z/ are found in 'xazn' $\rightarrow$ 'xanz' " to store".

45. The non-adjacent /q/ and /m/, 'daHqöm' $\rightarrow$ 'daHmöq' "a man who behaves well".

46. The non-adjacent $/ \mathrm{h} /$ and $/ \mathrm{j} /$ are repeated in two syllables in 'hajhajat' $\rightarrow$ 'jahjahat' "to enforce somebody to move".

47.The non-adjacent /T/ and /b/ exist in 'baTix' $\rightarrow$ 'Tabïx' "watermelon".

48 The non- adjacent /s/ and /1/ which are repeated in two syllables in the same word, as in: 'salsäl' $\rightarrow$ 'lasläs' "pure.

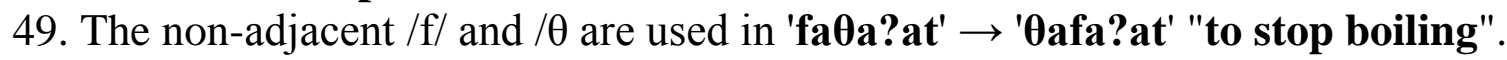

50. The non-adjacent $/ \mathrm{b} /$ and $/ \mathrm{k} /$ which are repeated in two syllables of the same word as in:

'bakbakat' , 'kabkabat' "to put something on something else".

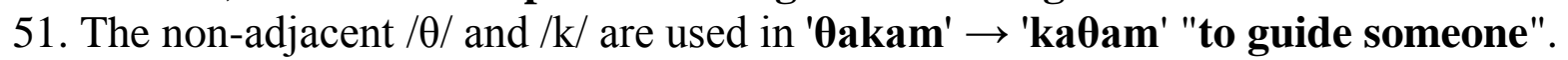

52. The adjacent /ç/ and /b/ exist in 'muçbnaqy' $\rightarrow$ 'mubçnaqy' " a boy who behaves badly".

53. The non-adjacent $/ \gamma /$ and $/ \mathrm{m} /$ which are repeated in two syllables of the same word, are found in 'yamyama' $\rightarrow$ 'maymaya' " the speech that can not be understood".

54. The non-adjacent / $\mathrm{x} /$ and /f/ are used in 'xanafir' $\rightarrow$ 'fanaxir' "a person with a big nose".

55. The order of three sounds is changed, that is, they are reordered in the opposite way, as in: /r/, /w/ /n/, as in: 'rwnaq' $\rightarrow$ 'nwraq' "beauty"; /z/, /ç/, /j/, as in: '?inzaçaj' $\rightarrow$ '?injaçaz'; /z/, /n/, /j/, as in: 'zinjir' $\rightarrow$ 'jinzir' "chain"; /h/, /l/, /ç/, as in: 'halaç' $\rightarrow$ 'çalah' "impatient". In those examples, the changes happen in the syllables, i.e. the sound moves from one syllable to another.

56. The non-adjacent $/ \mathrm{r} /$ and $/ \mathrm{H} /$ are switched in a word when they move from one syllable into another, as in: 'rumäHis' $\rightarrow$ 'Humäris' "a man who is dare to do anything"; 'TaHör' $\rightarrow$ 'TaröH' "a bow with a fast arrow".

57. The non-adjacent $/ \mathrm{m} /$ and $/ \mathrm{H} /$ are changed in their place from one syllable into the other, as in: 'TumäHir' $\rightarrow$ 'TuHämir' "a man with a big internal side of the mouth".

58. The adjacent /k/ and /l/ are used in: 'Hukla' $\rightarrow$ 'Hulka' "a person who speaks badly"; 'baklorya' $\rightarrow$ 'balkorya'.

59. The $/ \mathrm{b} /$ and $/ \mathrm{r} /$ can either be adjacent in a word or non- adjacent in another, as in: 'Saçbör' $\rightarrow$ 'Saçröb' "aperson who has a small head in comparison with other people"; 'fabraqat' $\rightarrow$ 'Jarbaqat' "to cut it"; 'Jahbara' $\rightarrow$ 'fahraba' "an old woman".

60. The non-adjacent $/ \theta /$ and $/ \mathrm{T} /$ which change their places from one syllable to another

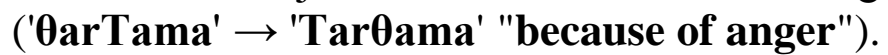

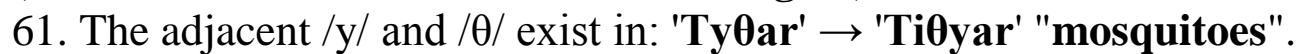

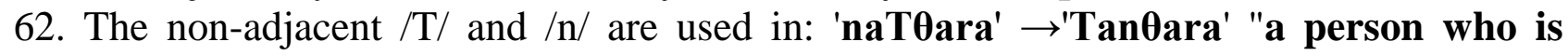
eating too much fat, so his body becomes heavy".

63. The non-adjacent /T/ and /// which can either change their place from one syllable into the other in a word or change their places in the same syllable in another word, are

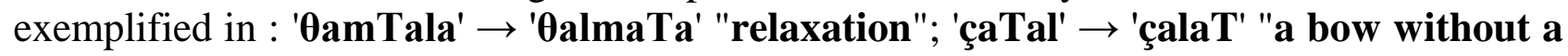
string".

64. The non-adjacent /s/ and /T/ are switched in: 'sarTaç' $\rightarrow$ 'Tarsaç' "a person who runs very fast".

65. The $/ \mathrm{J} /$ and $/ \mathrm{m} /$ can either be adjacent or non-adjacent as in: 'Tarfam' $\rightarrow$ 'Tarmaf' "it becomes dark"; and 'Hi $\int \mathrm{ma}^{\prime} \rightarrow$ 'Him $\int \mathbf{a}^{\prime}$ "anger". 
66. The non-adjacent $/ \gamma /$ and /f/ exist in: 'farfö $\gamma$ ' $\rightarrow$ 'faryöf' "a small frog".

67. The non-adjacent /f/ and /ç/, 'taqrçaf' $\rightarrow$ 'taqrfaç' "a person who is showing his fists".

68. The non-adjacent $/ \mathrm{x} /$ and /d/ which occur twice in the same word, are found in: 'xadxad' $\rightarrow$ 'daxdax' " a small animal".

69. The non-adjacent /r/ and /j/ are used in Standard Arabic, as in: 'Hibjir' $\rightarrow$ 'Hibrij' "the male of the bustard"; 'Habajir' $\rightarrow$ 'Habarij'; but they become adjacent in the metathetic form of the word which is taken from Jordanian Arabic, as in: 'rijlïn' $\rightarrow$ 'ijrïn' "the feet".

70. The adjacent /j/ and /H/ exist in: '?jHamat' $\rightarrow$ '?Hjamat' "to give it up" (Standard Arabic).

71. The adjacent /n/ and /f/ are used in: 'Janfat' $\rightarrow$ 'Jafnat' "to look at it".

72. The non-adjacent $/ t /$ and / $/$ / exist in: 'batalat' $\rightarrow$ 'balathu' "if it is broken".

73. The non-adjacent/l/ and /f/ move from one syllable to another, as in: 'lafat' $\rightarrow$ 'fatal' "to make his face away from the others".

74. The non-adjacent $/ \theta /$ and $/ \mathrm{n} /$ exist in: ' $\theta$ anat' $\rightarrow$ 'na $\theta a t^{\prime}$ "meat is stink".

75.The non-adjacent/f/and/T/ exist in: 'faTas' $\rightarrow$ 'Tafas' "the man is dead".

76. The non-adjacent /z/ and /H/ which are repeated in two syllables of the word: 'tazaHzaHat' $\rightarrow$ 'taHazHazat' "to be away from the place".

77. The non-adjacent /S/ and /b/ exist in: 'Subr' $\rightarrow$ 'buSr' "the side".

78. The non-adjacent /q/ and /1/ which are repeated in two syllables with a vowel in: 'qalqalat' $\rightarrow$ 'laqlaqat' "to clatter".

79. The non-adjacent $/ \gamma /$ and / $z /$ are used in: 'nayaza', 'nazaya' "insinuations of the devil". 80. The non-adjacent /s/ and /k/ are switched in: 'yatasakaç' $\rightarrow$ 'yatakasaç' "to proceed aimlessly".

81. /w/ and /H/ occur in: 'waH $\int \mathbf{y}^{\prime} \rightarrow$ 'Haw $\int \mathbf{y}^{\prime}$ "brutal speech".

82. /b/ and / // are switched in: '?wba $\int^{\prime} \rightarrow$ '?w $\int \mathbf{a b}^{\prime}$ "rabble".

83. /b/ and /D/ are changed in their places in: 'qabaDa' $\rightarrow$ 'qaDaba' "gripping"; '?nbaDa'

$\rightarrow$ '?nDaba' "to seep away in the ground".

84. The non-adjacent /n and /g/ are switched in a word taken from Iraqi Arabic: '?znag' $\rightarrow$ '?zgan' "the richest".

85. /ç/ and /r/ are adjacent in '?çrny' $\rightarrow$ '?rçny' "listen to me" while it is non- adjacent in: 'çarbön' $\rightarrow$ 'raçbön' "a sum of money"(Syrian Arabic).

86. The adjacent /?/ and /d/ exist in '?dab' $\rightarrow$ 'd?ab' "politeness".

87. The non-adjacent /y/ and /n/ exist in: 'diyana' $\rightarrow$ 'dinaya' "religion".

88. The non-adjacent /n/ and /S/exist in: 'tanaSut' $\rightarrow$ 'taSanut' "listening".

89. The non- adjacent /w/ and /n/ are used in: 'fawanïs' $\rightarrow$ 'fanawïs' "lanterns" in which they move from one syllable to another.

90. The non- adjacent / $\mathrm{j} /$ and / $\mathrm{d} /$ are switched in a word taken from Moroccan Arabic: 'sijad'

$\rightarrow$ 'sidaj' "carpets".

91. The /z/ and /b/ are switched in 'kazbara' $\rightarrow$ 'kabzara' "coriander" (Syrian).

92. The non-adjacent $/ \mathrm{n} /$ and /ç/ are interchanged in a word taken from Sudanese Arabic: 'naçja' $\rightarrow$ 'çanja' "sheep".

93. The non-adjacent /r/ and /d/ are switched in: 'rayd' $\rightarrow$ 'dayr' "the person who wants something", which is used in Sudanese Arabic

95. The non-adjacent $/ \mathrm{m} /$ and $/ \mathrm{z} /$ are interchanged in a word which is taken from Iraqi Arabic: 'mizyj' $\rightarrow$ 'zimyj' "mixture". 
96. In spoonerisms, the places of the words are changed like, 'sa?a Jalim' instead of 'ja?a Salim' "Salim is coming" (Al-Hamash, 1982: 220).

\subsection{Different points of view on Metathesis}

There are different view points on metathesis in English:

1. Hume (2001) considers metathesis as irregular and sporadic process because it is found in performance errors, child language or sound change.

2. To Webb (1979), it is not found as a regular phonological process in synchronic grammar.

3. To Montreuil (1981), it is seldom to find productive rules of metathesis which can be explained in terms of Historical Linguistics. A definitely marginal character is given to them by their sporadic nature. Synchronic metathesis is regarded as a performance factor which is in charge of spoonerisms and other erratic surface derivations.

4. Powell (1985) explains that metathesis is dealt with as a minor sound change in general.

5. It is focused by Spencer (1996) that it is often used in all languages as a kind of speech error and it is a feature which commonly distinguishes child phonology.

The points of view No. 1,2,3,4,5, are quoted in Banjar (2003: 10-1).

6. According to Besnier (1987: 202), it is extremely important to know that metathesis is one of the phenomena that involve a change in morphological and phonological systems of a language altogether. It is described as being less productive in comparison with other morphological phenomena.

7. Synchronically or diachronically, metathesis has usually been considered as one of the less common phonological processes. Even though there has been a question arisen which is whether it is found in a language as a synchronical (morpho)phonological process only or not (Butskhrikidze and Jeroen, 1427: 1).

8. Metathesis is one of the phonetic changes which have happened during the history of different European languages. They also cause little changes in pronunciation in every place and at any time. Some of them happen at a short period of time, but others are fixed and form part of the norm (Malmberg, 1963: 100 and Stageberg, 1981: 33).

9. Katamba (1992: 197-8) agrees with Gleason (1968) that metathesis is rarely used but it can be found in a number of languages like Arabic, English, etc. It is a morphological process which does not include a simple sequence of morphemes. But it is not easy to modify metathesis in terms of traditional theories.

10. For O'Grady et al (2005: 47), metathesis is described as a common articulatory process. It is a reordering of a sequence of sounds which are phones. The phones are metathesized because of their easiness to articulate.

On the other hand, the points of view on metathesis in Arabic are:

1. As quoted in Al- Samarai (1997: 120), Ibn- Faris considered metathesis as one of the Arabs' traditions.

2. Al- Samarai (ibid) describes metathesis as a "chaos" that the Arabs feel proud of and are accordingly distinguished from other people in the world. As clear in many linguistic sources, metathesis can not be regarded as a chaos because it is one of the linguistic phenomena, amongest others. The metathesized words are used in our everyday spoken dialects and have become more common than the original ones. In addition, linguists have to describe what the speakers say objectively since whatever is said by the native speakers is right. 
3. Ibn- Faris regarded many metathetic forms as colloquial since there are no such forms existing in the Holy Quran. Even though, there are some standard metathetic forms which exist in Standard Arabic (qtd in ibid).

4. According to Ibn-Duraid, a group of grammarians said that such metathetic forms are forms which discriminate the dialects, and are characteristic of the dialects in which they are used (qtd in ibid).

5. Metathesis is called 'Al-Qalb Al- Makäny' by the Morphologists and it is considered as a dialectal phenomenon (Al-Niaimi, 1980: 190).

6. Some metathetic forms, after becoming common and are used by many people, they become part of language by their being conjugated to other derivations. Not realizing that the Arab linguists judged these metathetic forms as original. Abu- Jaçfar Al- Nahas (one of the Arab grammarians), for instance, said that metathesis according to Basris (the Basris' school of Grammar) is like 'Ja?ik al- SiläH' and 'Jaki al- siläH' "thorny weapon"; ' juruf ha?ir' and 'juruf hary', which is not metathetic to the Kofis (the Kofis' school of Grammar) who considered them as dialects. Similarly, Al- Hariry (one of the Arab grammarians) said that Abdul- Qassim Al- Fadhil bin Mohammed Al- Nahwi (one of the grammarians) said 'jaðab' and 'jabað' "to attract" are dialects, that is, there is no original form and the other one is metathetic. Both are original since every one is used as original in its area and an infinitive is derived from each one. The infinitive of 'jabað' is 'jabaðun' is and the infinitive of 'jaðab' is 'jaðabun' (Al-Siyoti, 1998: 371).

7. Al-Sakhawi (qtd in ibid) also said that if there are original and metathetic forms, there will not be an infinitive for the metathetic form in order not to be mixed with the original one, such as: '?ayas' "to despair" and 'ya?s' "despair". But if there is, the form will be judged by the grammarians to be original.

\subsection{Types of Metathesis}

Changing the places of elements is found in some lexical items in many English dialects. Transposition is accompanied by either two consonants, one is often being a liquid; or a consonant and a vowel; ie a liquid and a vowel C/V : /prəpoz/ /pərpoz/ 'propose'. There is one instance in which $\mathrm{C} / \mathrm{C}$ and $\mathrm{C} / \mathrm{V}$ metathesis can be found: /brekfis//brefIks/'breakfast'.

In English, there are two ways of classifying metathesis. According to the first way, there are two types of metathesis: linguistic and quantitative metathesis. In linguistics, two sounds in the same word are switched with each other. In phonology, a place or a condition of two sounds is changed, i.e. transposition of sounds in one word. Such a change of sounds is to reorder two sounds in a word. Quantitative metathesis refers to two vowels which come after each other. Then, a transposition of length of those vowels happens. But in terms of the structure of the word, i.e. according to the sounds whether they are consonants or vowels, there are three types of metathesis. Two of them are found in English and the third one is used in other languages. The first one is known as "sporadic" which is /sp/ as /ps/, as in: 'wapse' for 'wasp' (CC), where there is no rule to put it under control. Lass (1984: 188) mentions that most metathetic forms are sporadic, i.e. happening only occasionally. The second one is "regular" which is represented by the change of places of $/ \mathrm{r} /$ and a vowel (VC or CV) (see also Hogg, 1977).

In English, metathesis is represented by two main modifications. The first type is that the places of a vowel and an adjacent consonant (VC) are exchanged and with the first type, the two items in a consonant cluster are used instead of each other, i.e. replace each other (CC). Concerning the second type, as an example, in the word 'rinnan' 'irnan' for 'run' 'brid' for 
'bird'. In the metathetic form, /r/ occurs before a vowel, then it changes its place to be after, particularly when a vowel comes before $/ \mathrm{n} /$ or $/ \mathrm{s} /$ and after some time, before $/ \mathrm{d} /$ in Late Northumbrian. Alternatively, the liquid comes before a vowel when it is after. This is common in Late Old Northumbrian. This is done when the vowel is used before the cluster/xt/ directly. In the first type of metathesis, two consonants in a cluster change their places. Two types of shift are used as examples for that type of metathesis. The first one is that /s/ followed by a stop, as in: (ascian/ axian [ks] 'ask', 'wasp'), but the other one is that a fricative /f, s, $\theta$ / followed by the liquid /l/ exchange their places in the same cluster. It is very rare to find a change of places of the two consonants in the following clusters: /sm, gn, kn, ns/ (Welna, 2008: 2).

The second type of metathesis (R-Metathesis) is the most commonest one in English. It has been noted that there is no enough satisfaction about the explanation of that type because it is not a matter of changing the places or the liquid and the vowel which are used only, that is,

(a) $\mathrm{VC}>\mathrm{CV}$
(b) $\mathrm{CV}>\mathrm{VC}$

Although this change can be explicated by abruptness hypothesis only, the simple pattern of change mentioned above was readily agreed on by the confessors of generative phonology. Concerning ( $a$ and $b$ ), there is an alternative theory in which an abrupt process of metathesis is accompanied by a gradual change, that is an insertion of a vowel before $[r]$ followed by a deletion of the vowel after [r] (Welna, 2008:3).

On the other hand, in Arabic, there are no such details or ways of classification like English, because there is one type of metathesis which is C-C. Metathesis is a phonological process of interchanging sounds in one word. The consonants are re-ordered in a word. This is done by fronting one sound and delaying the other. A new form is used instead of an old one which differs in that two parts have been switched. For example, 'lawan' $\rightarrow$ 'nawal' "to colour something" (Morrocan Arabic).

\subsection{The Reasons behind Metathesis}

Using metathesis is preferred for two reasons: the first is that it seems better for the speaker and hearer to produce the metathetic forms and the second is that the speaker finds easiness in pronouncing the consonants when he/ she tries to reorder the consonants in a word. So, euphony (sounding better) and ease of pronunciation give the meaning for metathesis in one of its linguistic uses (Casselman, 2007: 10).

While in Arabic, it has been decided that the real secret in most examples of metathesis is the difference of the phonetic chains in the words of language. For example, 'ya?s' "to despair" $\rightarrow$ '?ayas'. '?ayas' is the metathetic form of 'ya?s'. This is because a number of the roots which begin with hamza followed by 'ya?' is more than the number of roots which begin with 'ya?' followed by 'hamza'. So, 'ya?' and 'hamza' in 'ya?s' are switched to produce '?ayas' which is used in our everyday speech instead of 'ya?s'.

Metathesis is produced by the quick way of speaking and mispronunciation. The metathetic forms are often heard in standard language and colloquial dialects, but then the speaker tries to avoid the metathetic forms because there are rules that are followed. Metathesis is used by Bedouin dialects since they tend to speak quickly without any intentions to use exaggeration in using purified forms like those who live in the cities. The children imitate the adults in using the metathetic forms which are not corrected for them. 
so, such forms will spread in their speech. Then they will be generalized in other derivative forms (Al-Niaimi, 1980: 192).

One of the reasons is the difficulty of its original succession on the linguistic flavour. It is interpreted for easiness and facilitation purposes. In addition, as it is seen by Vandaris (qtd in Abdul-Tawab, 1997) that metathesis is committed due to fault and lack of concern (ibid: 89).

\subsection{Problems of Treating Metathesis}

In English and Arabic, there is a question which is not answered yet. What does the sequence $/ \mathrm{ps} / \rightarrow / \mathrm{sp} /$ mean? is it an 'interchange' or a movement of one sound over the other? Concerning the second case, which sound will move? The first or the second? There are three possible states to happen. In (a), /p/ can move to the right of $/ \mathrm{s} /$; in (b); /s/ can move to the left of $/ \mathrm{p} /$; both states can be found in (c). "The standard formulation for metathesis fudges the issue by not making a commitment". So, metathesis occurs, but how? There is no answer. Lass (1984: 188-9).

Metathesis is described by Chomsky and Halle (1986) quoted in Banjar (2003: 11- 2) in generative phonology, in terms of transformational notation which is:

$\mathrm{s} \quad \mathrm{k} \quad \mathrm{k} \quad \mathrm{s}$

$12 \rightarrow 21$. The output is $/ \mathrm{ks} /$.

This notation works with $\mathrm{CC}$ which are adjacent, but it does not work with $\mathrm{CV}$ or VC, or non-adjacent consonants and vowels like C1V2C3V4C5V6C7 $\rightarrow$ C7V2C3V4C5V6C1. So, the problem is still found.

\subsection{The Original and Metathetic Forms}

In English, there are no original or metathetic forms for speakers since both forms exist in their language. Both are one form used by the users. No speaker says this is original and that is metathetic, both forms are parts of language and meet the users' needs.

On the other hand, in Arabic, the rule is that the two forms in which one sound moves to be after or before the other, can be both the original ones. That means both forms can be the original. If this is not proved, one of them is the metathetic form from the other one. Then, the original and metathetic forms will be shown (Al-Niaimi, 1980: 190). This can be explained in four points:

a. Equality in Conjugation: If the two forms conjugate in a similar way, both of them will be the original, such as: 'jaðab' $\rightarrow$ 'jabað' "to attract".

b. Scope of Conjugation: If one form conjugates less than the other, the other one (the more derivative) will be the original. For example, 'ana' $\rightarrow$ 'än' "to come". There is the infinitive form for 'ana' which is 'alana' and there is no such form for 'än'. Even though IbnZayd mentioned an infinitive for 'än' which is 'alayn', saying that because both 'ana', 'än' have an infinitive, so they are original.

c. Correction with the existence of vowel gradation: If the form is not vowel graded, it is then a metathetic form because if it is original, it should have been vowel graded. For example, 'ya?s' $\rightarrow$ '?ayas' "to despair". 'ya?s' is the original form and '?ayas' is its metathetic one since it has no infinitive as it is mentioned in (b).

d. Abundance of Usage: When the word is used too much, it will be referred to as the original. So, 'ana' 'ya?ny' "to come" is the original form for 'än' 'ya?ïn' although there is an infinitive form which is mentioned by Abu-Zayd for 'än'. But such an infinitive was 
unknown or much used like the one for 'ana'. So, it was ignored by the scientists. Another example is 'ikfahar' "it becomes dark". Its infinitive is 'ikfihrar' for some grammarians like Ibn-Jini who depends on the abundance of usage in referring to the infinitive of the word while 'ikrahaf' for the others. But Al-Niaimi is against Ibn-Jini in this point commenting that no one can say that 'ikfihrar' and 'ikrahaf' are the infinitive forms for 'ikfahar' because they are used too much. We can not depend on the abundance of usage to decide which form is the infinitive for the other (Al-Niaimi, 1980: 191-2).

\subsection{Metathesis and Morphological Mizan}

The change that happens in the order of the segments of a word in Arabic becomes clear in the morphological mizan. There are four ways of knowing metathesis which are:

1. Not vowel grading a word which should be vowel graded (Al- I'laal): For example, the verb '?ayas' "to despair" will be subjected to the vowel gradation rule which says: if 'waw' or 'ya?' moves to the sound occurring before it and on which fathah is placed, 'waw' or 'ya?' will be changed to 'alif'. So, the verb ought to have been vowel graded which is as follows: '??s', as but it is not vowel graded. This proves that this verb is a metathesized form of the verb 'ya?s' "despaired" which does not subject to the rules of vowel gradation.

2. A word is being a diptote without anyone of the known preventions: For example, '?a yä?' "things" in Quran is a diptote although there is a word like '?ssmä?' "names"

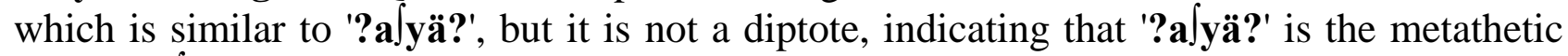
form of 'fay?ä?' "a thing" with its wazn 'façlä?' in which lam comes before fa?, so the word becomes '?a $\int \mathbf{y a ̈ ? ' ~ w i t h ~ i t s ~ w a z n ~ ' l a f c ̧ a ? ' . ~}$

3. Two roots with the same meaning

One root is used with many conjugations and the other is used without, such as: 'nä?a' and 'n?a' with the same meaning which is "to be far from". The forms which are derived from 'n?a' are 'alnä?i, yan?a, nä?in, man?i çanhu...'. So, the original form is 'n?a' and its metathetic form is 'nä?a' and its wazn is 'falaç'.

4. The rare usage of the same word with two forms

One is rarely used and the other is used too much. For example, the noun 'ri?m' "white antelope" has two plural forms: '?r?am' "white antelopes" with its wazn '?fçäl' which is of rare usage and 'äram, or ??ram' "white antelopes" which is of everyday usage. The latter is metathesized with its wazn '?çfal'. Other examples are 'ra?i' "opinion" and its plural form which is '?ara?' "opinions"; 'bi?r' "well" and its plural form which is '?abar' "wells".

5. Derivation

The examples are: 'jah' is the metathetic form of 'wajh' "face" and its wazn is 'çafl'; 'qisï' is the metathetic form of 'qwws' and its wazn is 'falöç'; 'Hadi' is the metathetic form of 'waHd' one and its wazn is 'çalif'; '?imDaHal' is the metathetic form of '?iDmaHal' "to vanish, disappear, to fade away" and its wazn is '?çfall'; '?ikraHaf' is the metathetic form of '?ikfaHar' "it becomes dark" and its wazn is '?iflaçall'.

6. Avoiding the successive hamzas in the final position of the word (nomen agentis with hamza on lam): For example, the verb 'ja?in' "to come" is taken from 'jay?' in which hamza comes before ya? to become 'ja?i' with wazn 'falin'; 'Sa?in' "he wants" is taken from 'Say?' in which hamza comes before ya?, so it becomes 'fa?i' with wazn 'fal' (Shabakat Rawa' Al- Adab: 2009).

\section{A Contrastive Study of Metathesis}


This section sheds light on the points of similarity and difference in metathesis in English and Arabic.

The similarities in metathesis between English and Arabic are:

1. In English, all dictionaries and references agree among each other that metathesis is a process of interchanging the places of sounds, syllables in a word or words or other units in a sentence. They define it as a phonological, phonetic or morphophonemic process. The same is with metathesis in Arabic. All Arabs give it one definition.

2. In the grammatical analysis of both languages, the problem of dealing with metathesis still exists. In the sequence of two sounds, is it a change in the place of the two sounds or a movement of one sound to be after or before the other? If the second case works, which sound moves? The first or the second one? There is no answer yet, although there is a number of notations suggested by linguists, it is not suitable to avoid the problem of how to deal with metathesis. So, some linguists have denied metathesis but others have not. They do not agree among each other on its existence in the language.

3. In English and Arabic, the original form keeps its part of speech and meaning when it changes to a metathetic one.

The differences in metathesis between English and Arabic are:

1. In English, metathesis is taken from Greek which was invented by Dionysius of Halicarnassus. It belongs to late 16th century. Most dictionaries and books agree upon its source with adding some information like the date and the meaning. In Arabic, the Arab ancient linguists referred to it with mentioning examples to make that phenomenon clearer for the reader.

2. In English, the sources for metathesis are historical development, the child's speech and the adult's speech while in Arabic, there is a reference to two sources of metathesis which are the child's speech and the speech of the adult.

3. In Arabic, the sounds which are metathesized are consonants only. So, there is one type of metathesis which is $\mathrm{C}-\mathrm{C}$. They can either be adjacent or non- adjacent. Sometimes, in the same word, the two sounds are adjacent but non- adjacent when the word is used in another dialect. In some words, the two metathesized sounds are used in two syllables, i.e. repeated in the same word. In other words, the order of three sounds is changed, that is they are reordered in the opposite way. There can be changes happening in the syllables, i.e. the sound moves from one syllable to another. While in English, there are two types of metathesis which are $\mathrm{C}-\mathrm{C}$ and $\mathrm{C}-\mathrm{V}$ or $\mathrm{V}-\mathrm{C}$ because the sounds which are switched can either be consonants or vowels. The sounds are adjacent more than being non- adjacent. Sometimes, there is an insertion of a vowel, especially the schwa in between the adjacent sounds in a word, so they become non-adjacent, sometimes accompanied by changes. In some words like the compound, a sound moves from one syllable into the other. In a word, the two sounds can either be adjacent or non-adjacent.

4. In both languages, metathesis is a change in the place of the sounds, syllables in a word and words in a sentence. But English is different from Arabic in that there is a change in the place of the distinctive features of the sounds in a word in addition to the sounds, syllables and words.

5. In English, the metathesized consonants and vowels are /1, r, k, s, p, d, d3, n, y, v, t, g and $\mathrm{m} /$, and /i/ and /ə/. But the most commonest among those sounds are the liquids / $/ /$ and $/ \mathrm{r} /$ and the fricative /s/. In English, in the C-C type, the most common consonants are a liquid and another $\mathrm{C}$, and $/ \mathrm{s} /$ is followed by a fricative but in the second $(\mathrm{C}-\mathrm{V} / \mathrm{V}-\mathrm{C})$, the most 
common $\mathrm{C}$ is $/ \mathrm{r} /$ and the vowel is /ə/. There can be found an example in which the two types of metathesis exist. While in Arabic, the metathesized consonants are $/ \mathrm{b}, \mathrm{t}, \mathrm{d}, \mathrm{T}, \mathrm{D}, \mathrm{k}, \mathrm{g}, \mathrm{q}$, ?, f, $\theta$, , $, \mathrm{s}, \mathrm{z}, \mathrm{S}, \mathrm{J}, \mathrm{j}, \mathrm{x}, \gamma, \mathrm{H}, \mathrm{c}, \mathrm{h}, \mathrm{l}, \mathrm{r}, \mathrm{m}, \mathrm{n}, \mathrm{w}, \mathrm{y} /$. But the commonest ones are the plosives /b, t, T/, fricatives /f, s, z, H, ç/, the nasals /m, n/ and the liquids /l, r/.

6. In Arabic, there are different points of view about whether this form is original and the other is metathetic or both are original. For most grammarians, both original and metathetic are dialectal features since every one is being needed by the people of each dialect. So, each one is considered an original form in its area where it is used. English linguists consider metathesis as not being regular, and it is sporadic due to its existence in the adult's speech, in the language of the child and in historical linguistics. It is rare to find it productive. It also exists in all languages of the world as a process which differentiates the children from each other in terms of their phonology. A linguist deals with it as being a phonetic process, another as being phonological and others as a morphological one.

\section{Conclusions}

Throughout this contrastive descriptive study, the following conclusions are arrived at:

1. Metathesis can be classified in one or two ways according to the metathesized sounds, i.e. consonants or vowels.

2. Sometimes, the metathetic form has the popularity more than the original form of the word. So, it will be used instead of the original one, i.e. the correct pronunciation. For example, the word 'modren' is used nowadays more than 'modern' which is the original word.

3. The transposition of sounds in a word is an evidence that the resulted sequence is easier to produce. For example, 'aks' is easier than 'ask'.

4. Producing a /CV/ syllable by English speakers is easier than pronouncing a /CC/ one. Euphony and ease of pronunciation are the main reasons for preferring consonant metathesis.

5. Metathesis occurs as a regular phonological process in synchronic systems in a wide range of languages.

6. Metathesis does not tend to be systematic because it can be used in individual words only but not all the sequences of sounds of those words can subject to metathesis rules.

7. Whether the form is metathetic or original is a relative issue. In the areas where the metathetic form is abundantly used, it is considered original and linguists are even unaware of its original form.

8. In English and Arabic, metathesis is less productive in contrast with the other morphological phenomena. This is because it is a reordering of sounds in the same word to produce a metathetic form which has the same semantic and syntactic features (i.e. meaning and part of speech) of the original form. There is only a change in the spelling and pronunciation of the words of languages.

\section{English References}

Akmajian, Andrian, Richard, A.Demers, Ann K. Farmer and Robert M. Harnish (2001). Linguistics: An Introduction to Language and Communication.

Cambridge: The MIT Press.

Babylon.com LTD. (2007). Babylon online dictionary. http://www.babylon.com/definition/metathesis/Arabic.

Besnier, Niko (1987). "An Autosegmental Approach to Metathesis in Rotuman". Lingua 73. North- Holland. 
Butskhrikidze, Marika and Jeroen, van de Weijer (1427). "On the Formal Description of Metathesis: A Case Study of v-Metathesis in Modern Georgian". ULCL-

Leiden University. E-mails: m.butskhrikdze@let.leidenuniv.nl and j.m.van.de.weijer@let.leidenuniv.nl.

Casselman, William Gordon (2007). "Canadian Word of the Day: Québec Expressions Today" : INDIGO.CA. Part 5.

http://www.billcasselman.com/quebec_sayings/qs_five_metathesis.htm.

Crystal, David (1992). An Encyclopedic Dictionary of Language and Languages. UK: Blackwell Publishers. (2003). A Dictionary of Linguistics and Phonetics. 5th ed. Oxford:

Blackwell Publishing.

G \& C. Merriam Co. (1913). Webster's Revised Unabridged Dictionary. Noah Porter (ed.). http://www.babylon.com/definition/metathesis/English.

Gleason, H.A. (1961). An Introduction to Descriptive Linguistics. New York: HOLT, RINEHART and WINSTON, Inc.

Harper, Douglas (2001). Online Etymology Dictionary . LogoBee.com. Page design and coding by Dan McCormack.

Hyman, Larry, M. (1975). Phonology: Theory and Analysis. New York: HOLT, RINEHART and WINSTON.

Katamba, Francis (1993). Morphology. Great Britain: Mackays of Chatham PLC.

Lass, Roger (1984). Phonology: An Introduction to Basic Concepts. Cambridge: Cambridge University Press.

Malmberg, Bertil (1963). Phonetics. New York: Dover Publications, INC.

Matthews, P.H. (2007). 2nd ed. Oxford Concise Dictionary of Linguistics. Oxford: Oxford University Press.

McARTHUR, TOM. (1998). "METATHESIS." Concise Oxford Companion to the English Language. Encyclopedia.com. <http://www.encyclopedia.com>. http://www.encyclopedia.com/doc/1O29-METATHESIS.html.

Minkova, Donka (2003). Alliteration and Sound Change in Early English. Cambridge: Cambridge University Press.

Nordquist, Richard (2009). "Metathesis". About.com: Grammar \& Composition. About.com. http://grammar.about.com/od/mo/g/metathesisterm.htm.

O'Grady, William, John Archibald, Mark Arnoff and Janie Rees- Miller (2005). 5th ed. Contemporary Linguistics: An Introduction. New York: Bedford/st. Martin's.

Parker, Philip M. (2009). "Metathesis". Merriam-Webster Online Dictionary with Multilingual Thesaurus Translation. INSEAD. http://www.merriam-

webster.com/dictionary/metathesis.

Pyles, Thomas and John Algeo (1982). The Origins and Development of the English Language. New York: Harcourt.

Richards, Jack. C, John Platt and Heidi Platt (1992). Longman Dictionary of Language Teaching and Applied Linguistics. 2nd edn. London: Longman.

Roach, Peter (1988). English Phonetics and Phonology: A Practical course. Cambridge: Cambridge University Press.

Stageberg, Norman C. (1981). $4^{\text {th }}$ ed. An Introductory English Grammar. New York: Holt, Rinehard and Winston.

Tessier, Anne-Michelle (2007). "Discussion from Last Class: Metathesis in Child 
Data". LING599.

http://www.ualberta.cal annemich/AMT500\%20week\%202\%20OTIntro.pdf.

The ODLT: The Online Dictionary of Language Terminology.

Verma, S.K. and N. Krishnaswamy (1989). Modern Linguistics: An Introduction.

Oxford: Oxford University Press.

Webster's 1828 Dictionary. http://1828.mshaffer.com/d/word/metathesis.

Welna, Jerzy (2008). "Metathetic and non-metathetic form selection in Middle

English". Studia Anglica Posnaniensia: international review of English Studies.

Yehudim, Netzarim (2007). The Merriam-Webster Word of the Day.

Yule, George (2006). The Study of Language. 3rd edn. Cambridge: CUP.

(2001). WordNet 1.7.1. Princeton University.

http://www.websters-online-dictionary.org/ap/aphesis.html\#top.

(2005). Webster's New World College Dictionary. $4^{\text {th }}$ ed. Ohio: Wiley Publishing, Inc.

Used by arrangement with John Wiley \& Sons, Inc.

(2007). Alpha Dictionary.com. Lexiteria LLC.

http://www.alphadictionary.com/goodword/word/metathesis.

(2009). "100 Most Often Misspelled Words and Phrases in English". Your

Dictionary.com. LoveToKnow, Corp.

http://www.yourdictionary.com/library/mispron.html.

(2009). "AllWords.com Multi-Lingual Dictionary". Allsites LLC.

http://www.allwords.com/word-metathesis.html

(2009). Dictionary.com Unabridged. Random House, Inc. Based on the Random

House Dictionary.

(2009). Compact Oxford English Dictionary. Oxford University Press.

(2009). Encarta® World English Dictionary [North American Edition] @ \& (P).

Microsoft Corporation.

(2009). RhymeZone. Datamuse.

http://www.rhymezone.com/r/rhyme.cgi?Word=metathesis.

(2009). The American Heritage ${ }^{\circledR}$ Dictionary of the English Language. $4^{\text {th }}$ ed.

Houghton Mifflin Company.

(2009). Wikipedia Encyclopedia. Wikipedia Foundation, Inc.

http://en.wikipedia.org/wiki/Metathesis_(linguistics).

(2009). Wiktionary A, the Free Encyclopedia.

\section{Arabic References}

Abdul- Tawab, Ramadhan (1988). Buhooth wa Maqalat fi Allugha (Researches and Articles in Language). $2^{\text {nd }}$ edn. Cairo: Maktabat Al- Khanchi.

. (1997). Al- Tatawir Allughawi: Madhahirahu wa Ilalahu

wa Qawaninahu (Linguistic Development: Its Phenomena, Reasons and Laws). $3^{\text {rd }}$ edn. Cairo: Maktabt Al- Khanchi.

Al- Faisal, Samer Ruhi (2007). Ta'liq 'ala Bahith Li Abdul-Rahman Al-Dagazli: AlDhawahir Allughawiyah Al- Kubra fi Al-Arabiyah (Commenting on AlDargazli's Research: The Biggest Linguistic Phenomena in Arabic Language).

Al- Hamash, K.I. (1986). Dictionary of Linguistic and Phonetic Terms: EnglishArabic. Baghdad: IDELTI.

Al- Niaimi, Hussam Saeed (1980). Al- Dirasat Allahjiya wal Sawtiya ind Ibn-Jini (Ibn-Jini's Dialectal and Phonetic Studies). Baghdad: Dar Al- Rasheedd 
Lilnashir.

Al- Samarai, Ibrahim ( 1997). Al- Tatawir Allughawi Al- Tarikhi (Historical

Linguistic Development). Beirut: Dar Al- Andulus.

Al- Siyoti, Jalal Adin Abdul- Rahman Bin Abi Bakir (1988). Al- Mizhir fi Iloom

Allgha wa Anwa'iha (Al-Mizhir in Sciences of Language and its Types). Vol.1.

Beirut: Dar Al- Kutub Al- Ilmiya.

Aziz, Yowell Y. (1989). A Contrastive Grammar of English and Arabic. Mosul:

Univerity of Mosul Publication House.

Baalbakani, Rohi and Munir Baalbakani (2006). Al-Mwarid Al- Waseet: Concise Disctionary: English-Arabic, Arabic-English. Beirut: Dar El-Elm Lilmalayin.

Banjar, Shadia Yousef (2003). " A Synchronic Study of Metathesis in Eastern Arabic with Reference to Makkan \& Cairene Dialects", Bulletin of the Faculty of Arts. 14. pp: 1-47.

Betti, Mohammed Jasim. (1998). "The Employment of English Lexicons by Adolescent Speakers of Nassiriya Iraqi Arabic as Determined by Sex Differentiation". Al- Qadisya journal, 3, 2, 72- 9.

Hanna, Sami, A., Karim Zaki Husam Al-Din and Naguib Greis (1997). Dictionary of Modern Linguistics: English- Arabic. Beirut: Librairie du Liban Publishers SAL.

Hassan, Tammam (2004). $4^{\text {th }}$ ed. Allugha Al-Arabiya: Ma'naha wa Mubnaha (Arabic Language: Its Meaning and Construction). Cairo: Alam Al- Kutub.

Shabakat Rawa' Al- Adab (2009). "Metathesis ... From Morphological Mizan".

Powered by vBulletin Version 3.8.4. Jelsoft: Enterprises Ltd.

Rabin, Cham (1986). Allahjat Al-Arabiya Al- Gharbiya Al- Qadïma (Ancient Arab Western Dialects). Abdul- RaHman Ayüb (tr.). Kuwait: ðat Al-Salasil Liltibaa wal Nashir.

(2005). Ta'qïb 'ala Bahith min Al-Dhawahir Al-Sawtiyah fi Lahjat Al-Qasim: Dirasa fi Dhaw' Kutub Al- Turath Allughawi (Commenting on Research of Phonetic Phenomena in Al- QaSïm Dialect: A Study in the Light of Linguistic Heritage). Majalt Al- Dirast Allughawiyah. Markaz Al-Malik Faisal Lilbuhooth wal Dirasat A1- Islamiyah. Maj.7. P219.

\section{a. English Phonemes}

Appendix I: The Symbols of English and Arabic Phonemes ${ }^{3}$
$\mathrm{i}$ as in 'pit' /pit/
i: as in 'key' /ki:/
e as in 'pet' /pet/
a: as in 'car' /ka:/
a as in 'pat' /pat/
$\mathrm{o}$ : as in 'core' /ko:/
$\wedge$ as in 'putt' $/ \mathrm{p}^{\wedge} \mathrm{t} /$
$\mathrm{u}$ : as in 'coo' /ku:/
o as in 'pot' /pot/
3: as in 'cur' / $\mathrm{k}$ 3:/
$\mathrm{u}$ as in 'put' /put/
ə as in 'about' /abaut/
ei as in 'bay' /bei/
ou as in 'go' /g əu/
ai as in 'buy' /bai/
au as in 'cow' / kau/
oi as in 'boy' /boi/

3. A list of English phonemes are taken from Roach (1988: 6) and a list of Arabic Phonemes with examples are taken from Banjar (2003: 17-18) and Betti (1998: 77). 
iə as in 'peer' /piə/

eə as in 'pear' /peə/

uə as in 'poor' /puə/

$\mathrm{p}$ as in 'pea' /pi:/

b as in 'bee' /bi:/

$\mathrm{t}$ as in 'toe' /tou/

$\mathrm{d}$ as in 'doe' /dəu/

$\mathrm{k}$ as in 'cap' /kap/

$\mathrm{g}$ as in 'gap' /gap/

f as in 'fat' /fat/

$\mathrm{v}$ as in 'vat' /vat/

$\Theta$ as in 'thing' / Oin/

ð as in 'this' /ðis/

$\mathrm{s}$ as in 'sip' /sip/

$\int$ as in 'ship' / $\mathrm{ip} /$

$\mathrm{z}$ as in 'zip' /zip/

$\mathrm{h}$ as in 'hat' /hat/

3 as in 'measure' /me3ə/

$\mathrm{m}$ as in 'map' /map/

1 as in 'led' /led/

$\mathrm{n}$ as in 'nap' /nap/

$r$ as in 'red' /red/

$\mathrm{y}$ as in 'hang' /hay/

$\mathrm{j}$ as in 'yet' /jet/

$w$ as in 'wet' /wet/

t $\int$ as in 'chin' / $t$ in/

d3 as in 'gin' /d3in/

\section{b. Arabic Phonemes}

$i$ as in 'min' "from"

e as in 'lemese' "He touched"

ï as in 'fil' "elephant"

a as in 'katib' "writer"

ë as in 'bët' "house"

$\mathrm{u}$ as in 'qum' "Stand"

ä as in 'qäla' "He said"

$o$ as in 'bol' "empty"

ü as in 'maxbül' "crazy"

ö as in 'xöf' "fear"

The unique Arabic consonants include the following:

$\mathrm{T}$ as in 'Tib' "medicine"

D as in '?rD' "land"

$\mathrm{q}$ as in 'qabr' "grave"

? as in 'mu?min' "believer"

ž as in '?ža' "He came"

$\mathrm{S}$ as in 'Sabr' "patience"

Z as in 'Zahr' "back"

$\mathrm{x}$ as in 'xubz' "bread"

$\gamma$ as in ' $\gamma$ arb' "West"

$\mathrm{H}$ as in 'Himmar' "donkey"

ç as in 'çalaa' "on"

Other consonants are:

b as in 'bab' "door"

$\mathrm{t}$ as in 'tamr' "dates"

$\mathrm{d}$ as in 'darb' "road"

$\mathrm{k}$ as in 'kataba' "He wrote"

$\mathrm{g}$ as in 'gäm' "He stood up"

$\mathrm{f}$ as in 'fäza' "He won"

$\Theta$ as in 'Oaman' "price"

s as in 'sabba' "He insulted"

ð as in 'ðäda' "He defended"

$\mathrm{z}$ as in 'zara' "He visited"

$\int$ as in 'fams' "sun"

$\mathrm{h}$ as in 'hajara' "He deserted"

$\mathrm{j}$ as in 'jäb' "He brought"

1 as in 'lima' "why?"

$r$ as in 'ramäd' "ash"

$\mathrm{m}$ as in 'mawt' "death"

$\mathrm{n}$ as in 'när' "fïre"

y as in 'yabkï' "He cries"

w as in 'wädi' "valley" 


\section{a. The English Data}

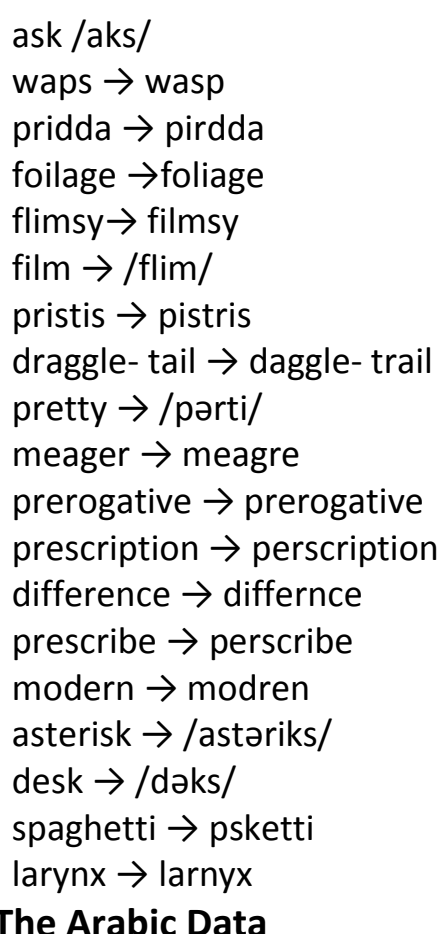

b. The Arabic Data an other $\rightarrow$ another

cavalry /kavlri/ $\rightarrow$ /'kalvəri/

relevant /'reləvənt/ $\rightarrow$ /'revələnt/

comfortable /k^mftərbəl/ $\rightarrow$ /k^mftəbl/

introduce /intrədju:s/ $\rightarrow$ /intərdju:s/

pronunciation $\rightarrow$ pernunciation

integral/intigral/ $\rightarrow$ /intragəl/

nuclear /njukliə/ $\rightarrow$ /nukular/

miraculum $\rightarrow$ milagro

emnity $\rightarrow$ enmity

animal $\rightarrow$ /aminal/

anemone $\rightarrow$ anenome

tragedy /traæd3ədi/ $\rightarrow$ tradegy /tradəd3i/

algum $\rightarrow$ almug

interesting /intəresting/ $\rightarrow$ intersting /intarsting/

jewelry /joowəlrie/ $\rightarrow$ julary /joolərie/

You occupy my pew $\rightarrow$ You occupew my pie [py]

the dear old queen $\rightarrow$ the queer old dean

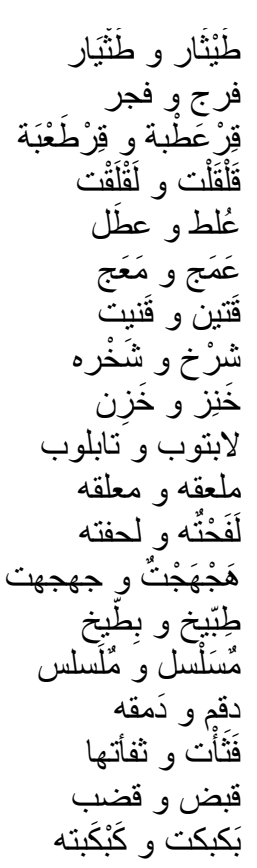

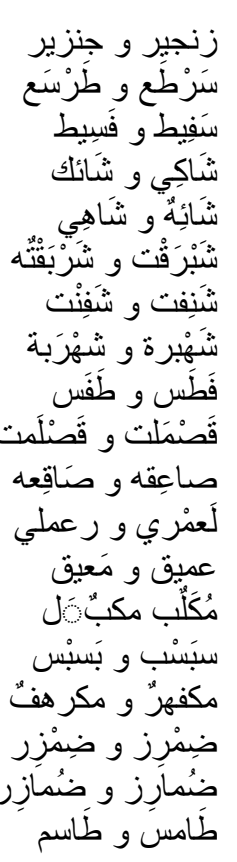

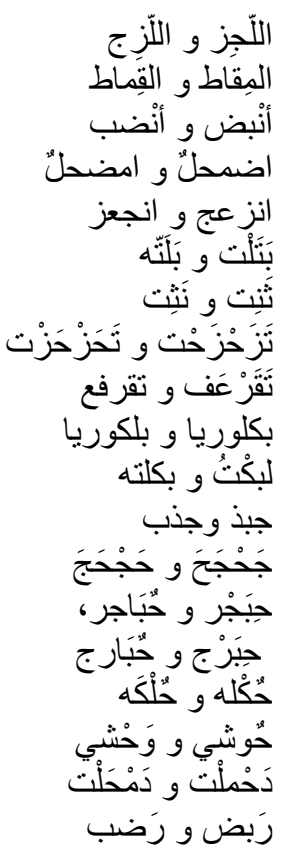

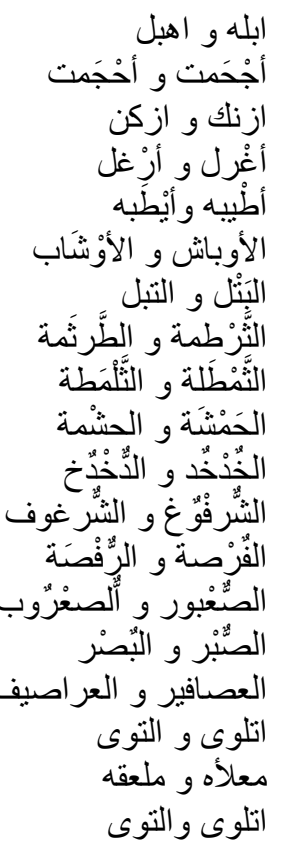




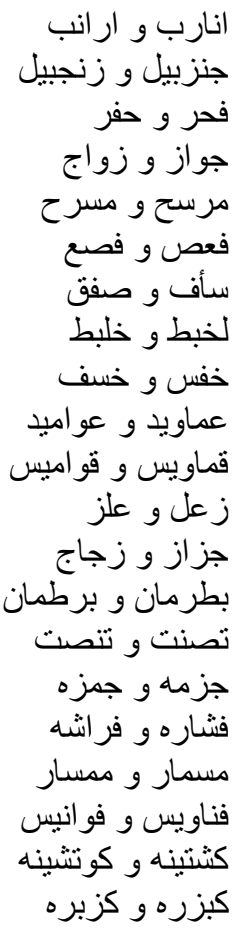

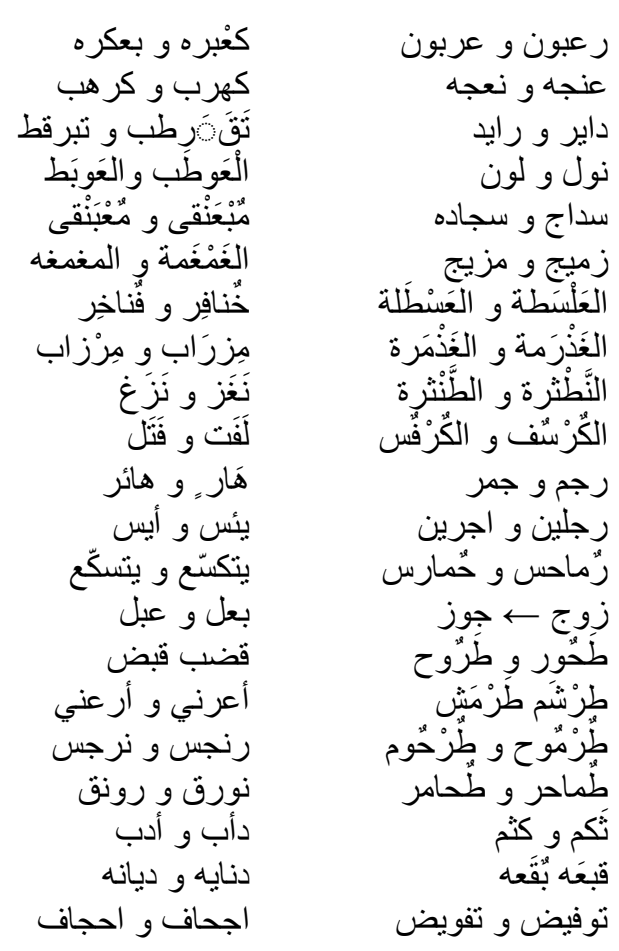

القلب المكاني هي إحدى ابرز الظواهر في بعض اللغات مثل الانكليزية و العربية الفصحى و العاميه و اللغات

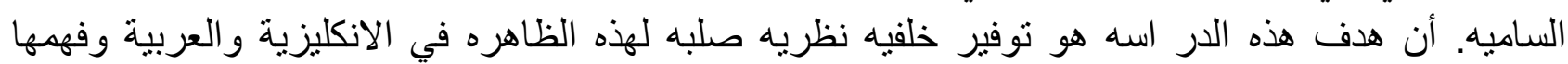

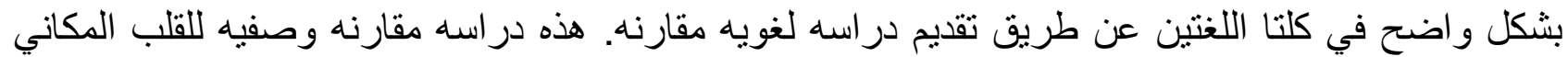

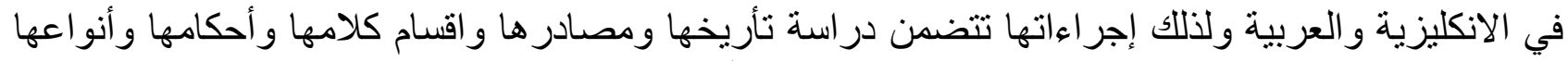

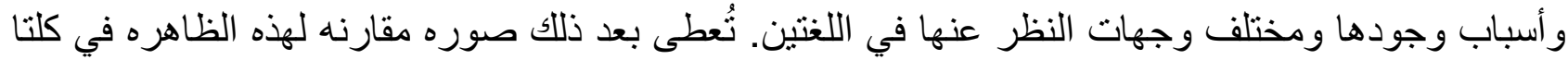

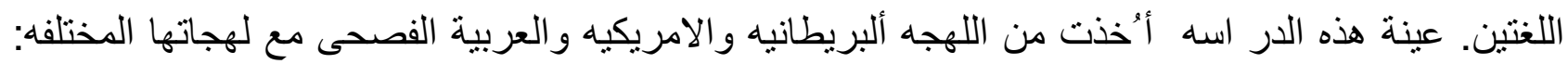

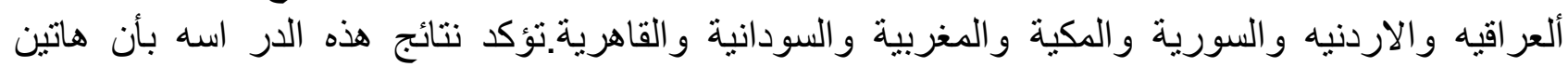

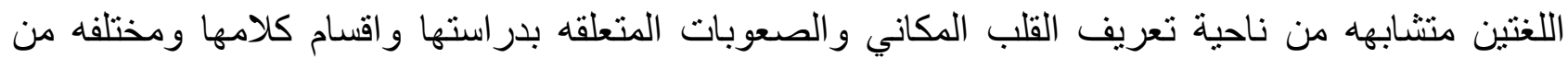

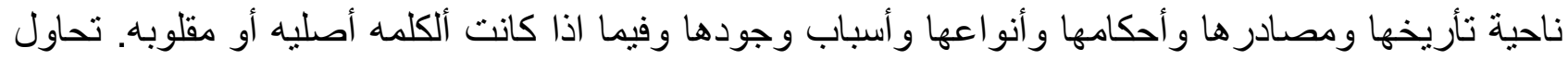

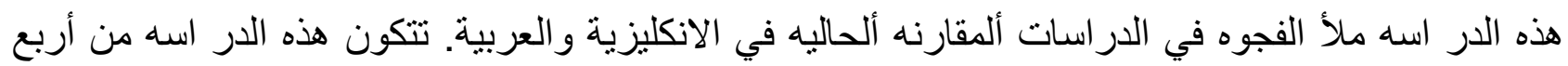
مباحث وتنتهي بقائمه من المصادر الانكليزية و العربية وملحقين. 